\title{
E-commerce as a tool for the development of small business
}

\author{
Niiara Demiroglu* \\ Crimean Engineering and Pedagogical University the name of Fevzi Yakubov, Simferopol, Russia
}

\begin{abstract}
E-commerce has gained particular importance for the development of small businesses in the past year due to the restrictions imposed due to the spread of the new coronavirus infection. The article provides a review of scientific literature in order to generalize the methodology for defining the concept of "electronic commerce". The main trends in the field of e-commerce in small business are characterized. The data on the development of the e-commerce market are analyzed and the following is emphasized: in the number of purchases from mobile devices has increased; creation and widespread use of social media pages is a key factor in the development of e-commerce by entrepreneurs. The advantages and disadvantages of using electronic commerce by small businesses are systematized. Conclusions are made about the growth in the volume of transactions using Internet technologies, and about the increase in digitalization of small businesses.
\end{abstract}

\section{Introduction}

During the COVID-19 pandemic, the business environment has undergone significant changes. Reduction in revenue, especially for small businesses, led to the search for new ways to sell goods and services. So, an effective technology should be noted the use of ecommerce (electronic commerce), which provided an opportunity to maintain competitiveness in the market in the context of the current economic crisis. "The development and expansion of online commerce leads to more rapid globalization and accelerated information exchange. At the same time, the development of Internet commerce is one of the main global trends in the development of the economy," notes V.K. Shaidullina [12]. At the same time, A.Ts. Choyzhalsanova and E.V. Bazarova note that "there is no generally accepted interpretation of the term 'electronic commerce"' [4]. A review of the scientific literature on the issue under consideration allowed the author to summarize various approaches to the definition of "e-commerce" in Table 1.

\footnotetext{
* Corresponding author: dnib2008@ukr.net
} 
Table 1. Approaches to the definition of "electronic commerce" in the economic literature.

\begin{tabular}{|c|c|}
\hline Definition & Authors \\
\hline $\begin{array}{c}\text { E-commerce is a sphere of the economy that includes trade and financial } \\
\text { transactions carried out using Internet technologies and automated } \\
\text { information systems }\end{array}$ & $\begin{array}{l}\text { A.Ts. Choyzhalsanova, } \\
\text { E.V. Bazarova } \\
\text { [4] }\end{array}$ \\
\hline $\begin{array}{l}\text { E-commerce is a trade through the use of electronic technologies } \\
\text { (Internet, sites and applications). }\end{array}$ & $\begin{array}{l}\text { I.V. Soklakova, } \\
\text { I.L. Surat } \\
\text { [6] }\end{array}$ \\
\hline $\begin{array}{l}\text { E-commerce (e-business) is any business activity that uses the } \\
\text { capabilities of global information networks to transform internal and } \\
\text { external relations in order to create profit. }\end{array}$ & $\begin{array}{l}\text { Ya.A. Lopatkova, } \\
\text { J.S. Belyaeva } \\
\text { [13] }\end{array}$ \\
\hline $\begin{array}{l}\text { E-commerce (electronic trading) is buying or selling online, while it } \\
\text { should be considered comprehensively as a chain of business processes } \\
\text { that provide transactions, financial and logistics support }\end{array}$ & $\begin{array}{l}\text { T.I. Smotrova, } \\
\text { T.S. Narolina } \\
{[11]} \\
\end{array}$ \\
\hline
\end{tabular}

In the works of scientists-economists there is no single methodology for the definition of the term "e-commerce". The use and interpretation of such concepts as "e-commerce", "ebusiness", "e-trading" is given. Electronic trading as an element of electronic commerce is also considered by S.Yu. Revinova, and summarizes the main trends in the development of e-commerce in Russia [9, p. 488]. The specifics of business development in the Russian ebusiness system and the characteristics of business models are given in the articles by A.I. Khisaeva, G.F. Shaikhutdinova, E.M. Ishmukhametov, M.A. Rizvanova [2, 3]. I. D. Bekmurzaev and Kh.K. Dugzaeva note the growing popularity of e-commerce, and its important place in business development [5]. Electronic trading in line with the concepts of the network economy and the digital economy is considered by A.G. Koval and M.Yu. Evdokimova. Researchers believe that "e-trading as part of the network economy brings new significant opportunities for doing business: companies can operate with qualitatively new, improved methods of work, reduce costs, find new sales markets, and also be more efficient in making management decisions" [1]. The author of the article proposes to consider e-commerce as an entrepreneurial activity aimed at selling goods, works, services in order to make a profit through the use of digital information technologies.

The review of scientific works indicates the need to generalize modern trends in the development of e-commerce for small businesses, taking into account the impact of the restrictions imposed due to the spread of a new coronavirus infection in 2020, as well as the features of digitalization of small businesses in Russia generalized by the author [8].

\section{Research methodology}

The article takes e-commerce of small businesses in Russia as an object of research. The method of referring to small businesses is considered by the author of the article in a previously published work [7]. The subject of the research is the development trends at the current stage of economic development. In preparing the work, the methods of analysis and synthesis, comparison of statistical data were used. The research was based on data from the non-profit organization AITC (Association of Internet Trade Companies). Analytical information is summarized within the framework of expert assessments and analysis of internal data of small businesses - participants of the Internet market. 


\section{Research results}

The study made it possible to summarize the main trends in the development of e-commerce in the field of small business with a view to their further application by entrepreneurs, since the rapid growth in the volume of sales of goods and services using Internet technologies is characteristic of both domestic and foreign markets and is a highly effective area of business dimension during the COVID-19 pandemic.

\section{Results and discussion}

The small business e-commerce industry has gone through five years of digital transformation in the months of the pandemic and continues to grow at a rapid pace. A sharp increase in trade is expected for the current year.

E-commerce is an ever-changing industry. Every year, new trends emerge that, if properly implemented, will help small businesses grow. Already today, technologies such as voice shopping, AR / VR browsing using artificial intelligence are becoming a new reality and are crucial in promoting online business and working with clients. 2021 is no exception and offers its own adjustments. Some trends have been demonstrating their relevance for a long time, others are just beginning to take over the electronic space from entrepreneurs.

Next, we will consider the main trends in the field of e-commerce for small businesses.

Online trading continues to grow steadily. E-commerce continues to grow exponentially. Not surprisingly, the main advantage that motivates millions of people to shop online again and again is ease, comfort and time-saving. The increased trust in online retailers is also an important factor.

To date, large-scale work is underway to improve the efficiency of online platforms. Searching through the catalog pages becomes convenient, intuitive, and a well-built marketing strategy not only does not irritate users, but, on the contrary, encourages them to buy. A bonus to everything is the convenience and variety of payment methods. As a result, a "win-win" situation is formed, where both the entrepreneur and the buyer win.

Figure 1 summarizes the evidence for the extensive growth of e-commerce.

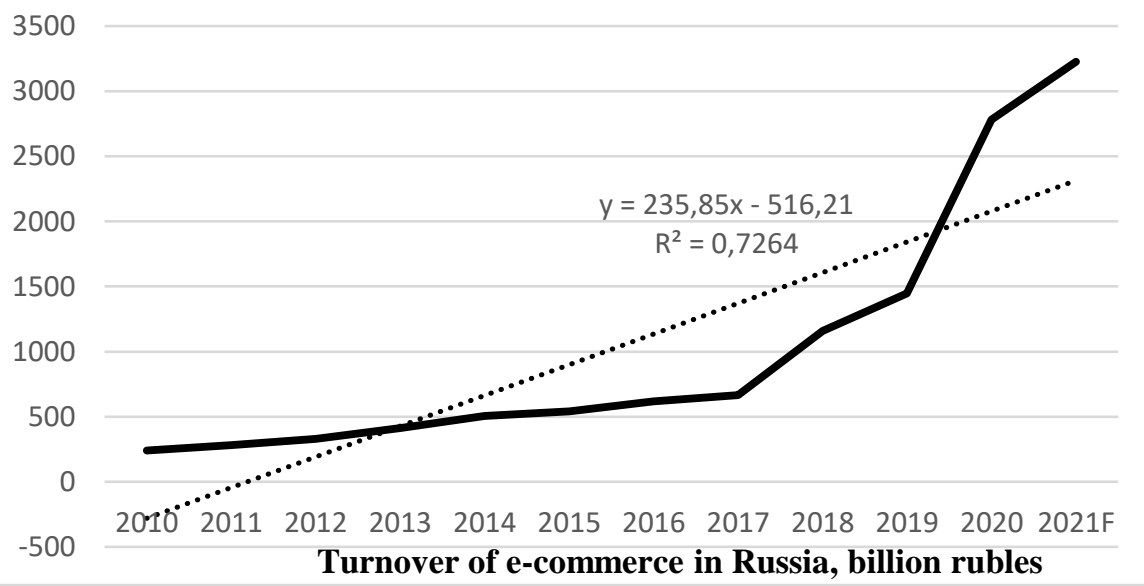

Fig. 1. Turnover of e-commerce in Russia for 2010-2020 [10].

Mobile shopping will continue to gradually replace desktops. The increase in the number of purchases from mobile devices is another fast growing trend. Mobile sales are expected to 
grow by $15 \%$ by the end of 2021 , bringing total mobile sales to $73 \%$ of all e-sales. Plus, mobile shoppers are "getting older". Users from 25 to 44 years old began to order from smartphones more often and caught up with 18 -year-olds by this indicator. The older audience is gradually coming up [10].

The growth of mobile commerce is not accidental. In recent years, the mobile device market has literally exploded with the number of new products and flagship devices that delight users with the ease of shopping. The number of mobile device users also continues to grow steadily. At the same time, entrepreneurs and developers are actively working on adapting their platforms for mobile devices in order to make mobile businesses as convenient and as functional as possible than on full-size devices. Consumers are now using mobile devices not only for shopping, but also for exploring products before buying. And thanks to advertising on social networks and a well-tuned campaign, it becomes easier to tell about the benefits of the product and attract the necessary category of users.

Social media is a new platform for small businesses. Social networks have long ceased to be just a means of communication, a link between people. They have evolved into powerful marketing tools that enable brands to recruit and expand their target audiences. Instagram and Facebook are already equipped with buy buttons, allowing merchants to conduct business within the ecosystem. Online stores, in turn, use social media to promote a product or service.

A competent strategy for promoting a brand on social networks can attract a significant amount of new traffic, increase sales, and make a brand recognizable and discussed. In 2021, the absence of a page on social networks is equivalent to the absence of a company at all. Both small and large brands are starting up accounts, and are actively working on creating a presence strategy.

Instant delivery as a factor of the stable development of small businesses. Delivery of goods is perhaps one of the key processes in e-commerce which should be given special attention. The pandemic has accelerated the projected growth of e-commerce in small businesses and has bolstered interest in online shopping. As a result, the load on courier services has increased significantly. But, as you know, any problem is just an excuse to optimize resources and redistribute forces, so entrepreneurs are puzzled by the introduction of faster and more stable delivery methods. The logistics issue has become more relevant than ever.

New payment options for more security and convenience. A variety of payment options that will satisfy the interests of different audiences remains one of the competitive advantages of some brands, in contrast to others. In 2021, more and more e-commerce companies are expected to start accepting payments in new formats, such as cryptocurrency. This type of payment offers lower transaction processing fees and faster transfers. However, many have noted an increased risk of cyber fraud and computer attacks.

Conclusions. It becomes obvious that e-commerce in small businesses continues to gain momentum rapidly. Companies continue to rethink their policies and values, begin to actively declare their presence on social networks, voice their position on the environment, optimize the interface and continue to work out logistics issues. The trends that are summarized in the article can be considered as a kind of vectors for the development of small businesses.

The study of the features of the use of e-commerce has provided an opportunity to systematize the advantages and disadvantages of using e-commerce by small businesses. The advantages include: no need for regional location of the business entity; availability for buyers of goods, works and services around the clock; reducing the cost of maintaining the store; growth of the brand image presented online; ability to sell digital goods. The disadvantages include: prevalence of offline trading; dependence on stable software; high level of competition; search for buyers and their trust. 


\section{References}

1. A.G. Koval', M.Y. Yevdokimova, Rossiyskiy vneshneekonomicheskiy vestnik 9, 79 (2020)

2. A.I. Khisaeva, G.F. Shaykhutdinova, E.M. Ishmukhametov, Advances in Economics, Business and Management Research 138, 603 (2020)

3. A.I. Khisayeva, G.F. Shaykhutdinova, M.A. Rizvanova, The European Proceedings of Social and Behavioural Sciences, 112 (2020).

4. A.TS. Choyzhalsanova, E.V. Bazarova, Fundamental'nyye issledovaniya 2, 78 (2021)

5. I.D. Bekmurzayev, K.K. Dugzayeva, FGU SCIENCE 1(17), 19 (2020)

6. I.V. Soklakova, I.L. Surat, Vestnik universiteta 5, 120 (2018)

7. N.B. Demiroglu, Published by Network Institute of Continuing Professional Education (2019)

8. N.B. Demiroglu, Economics, Business and Management Research 138, 70 (2020)

9. S.Y. Revinova, Vestnik Rossiyskogo universiteta druzhby narodov. Seriya: Ekonomika 25(4), 487 (2017)

10. Rynok internet-torgovli 2020 - Analitika AKIT (akit.ru)

11. T.I. Smotrova, T.S. Narolina, Ekonominfo 17(1), 55 (2020)

12. V.K. Shaydullina, Vestnik universiteta 3, 114 (2019)

13. Y.A. Lopatkova, Z.S. Belyayeva, Vestnik UrFU. Seriya ekonomika i upravleniye 18(1), 48 (2019) 